\title{
Parasitoid wasps new to Britain (Hymenoptera: Platygastridae, Eurytomidae, Braconidae \& Bethylidae)
}

\author{
David G. NOTTON ${ }^{1, *}$, Ovidiu A. POPOVICI ${ }^{2}$, Cornelis VAN ACHTERBERG ${ }^{3}$, \\ Jeroen DE ROND ${ }^{4} \&$ John T. BURN ${ }^{5}$
}

\footnotetext{
${ }^{1}$ Life Sciences Department, Natural History Museum, Cromwell Road, London SW7 5BD, UK E-mail: d.notton@nhm.ac.uk

${ }^{2}$ University “Al. I. Cuza” Iasi, Faculty of Biology, B-dul Carol I, no. 11, RO - 700506, Romania E-mail: popovici_alin_ovidiu@yahoo.com

${ }^{3}$ Naturalis Biodiversity Center, Terrestrial Zoology, Postbus 9517, 2300 RA, Leiden, The Netherlands E-mail: cees.vanachterberg@naturalis.nl

${ }^{4}$ Beukenhof 96, NL-8212 EB, Lelystad, The Netherlands

E-mail: jeroen@naturalmedia.nl

${ }^{5} 15$ Plawsworth Road, Sacriston, County Durham, DH7 6PD, UK

E-mail: dryinids@hotmail.co.uk

* corresponding author: d.notton@,nhm.ac.uk

${ }^{1}$ urn:1sid:zoobank.org:author:2E452EF2-703C-47C0-8432-6AB9C05AC06A

2 urn:Isid:zoobank.org:author:3BA67B09-2ECE-4BEC-908C-BB0F0FC30CEF

${ }^{3}$ urn:Isid:zoobank.org:author:D6374CF4-8F07-4FA8-8C55-9335FD19CECD

${ }^{4}$ urn:lsid:zoobank.org:author:29D036B9-0385-488E-AF25-2F8DCF8D3509

${ }^{5}$ urn:1sid:zoobank.org:author:B4B63601-6F87-4832-9AFD-F8D169638398
}

\begin{abstract}
One genus and five species are recorded as new to Britain: Fidiobia, Fidiobia hispanica, Macroteleia bicolora (Platygastridae); Sycophila binotata (Eurytomidae); Schizoprymnus collaris (Braconidae); and Laelius pedatus (Bethylidae). Keys to British Macroteleia and Laelius are provided. Provisional synonymy is proposed between Macroteleia minor and M. brevigaster, and synonymy is proposed between Laelius femoralis, L. microneurus and L. nigricrus. The possible mode of introduction of Sycophila binotata is discussed. A lectotype is designated for Schizoprymnus collaris.
\end{abstract}

Keywords. Conservation, identification keys, invasive species, lectotype designation, synonymy

Notton D.G., Popovici O.A., van Achterberg C., de Rond J. \& Burn J.T. 2014. Parasitoid wasps new to Britain (Hymenoptera: Platygastridae, Eurytomidae, Braconidae \& Bethylidae). European Journal of Taxonomy 99: 1-20. http://dx.doi.org/10.5852/ejt.2014.99

\section{Introduction}

Knowledge of the composition of the British Hymenoptera fauna is essential for the purposes of biological studies requiring accurate identifications, and their applications, including conservation of 
native species and the monitoring of faunal change. There are many species of parasitoid wasps and, even though the fauna is relatively well known, taxa new for Britain are regularly discovered.

This paper records one genus and five species found in material recently acquired by the Natural History Museum, London. The following are recorded as new to Britain: Fidiobia Ashmead, 1894, Fidiobia hispanica Popovici \& Buhl, 2010, Macroteleia bicolora Kieffer, 1908 (Platygastridae); Sycophila binotata Fonscolombe, 1832 (Eurytomidae); Schizoprymnus collaris (Thomson, 1874) (Braconidae); and Laelius pedatus (Say, 1836) (Bethylidae). Brief notes are provided on identification, material examined, distribution and biology of each taxon.

A key to British Macroteleia is given and provisional synonymy is proposed between Macroteleia minor and $M$. brevigaster; other recent additions to the British platygastrid fauna are noted by Notton (2006) and Buhl \& Notton (2009). Notes are provided on the distribution and possible mode of introduction of Sycophila binotata, which have implications for studies of recruitment of parasitoids of introduced gall wasps. A lectotype is designated for Schizoprymnus collaris. A key to British Laelius Ashmead, 1893 is given and synonymy is proposed between L. femoralis (Förster, 1860), L. microneurus (Kieffer, 1906) and L. nigricrus (Kieffer, 1906).

\title{
Material and methods
}

Images were taken using a Canon EOS 450D camera with aPentax $50 \mathrm{~mm}$ macro, with a number of partially focused images combined using Helicon Focus v.4.80 software. The method for measuring the Fidiobia is as described by Popovici \& Buhl (2010). Except where stated otherwise, all material is deposited in the collection of the Natural History Museum, London (BMNH).

\section{Results}

\author{
Class Hexapoda Blainville, 1816 \\ Order Hymenoptera Linnaeus, 1758 \\ Suborder Apocrita Latreille, 1810 \\ Superfamily Platygastroidea Haliday, 1833 \\ Family Platygastridae Haliday, 1833 \\ Subfamily Sceliotrachelinae Brues, 1908 \\ Genus Fidiobia Ashmead, 1894
}

Fidiobia hispanica Popovici \& Buhl, 2010

Figs 1-3

Fidobia synergorum - O'Connor et al., 2004: 14 [not Kieffer, 1921] [misidentification].

\section{Identification}

Specimens were identified to genus using the key by Masner \& Huggert (1989) and to species with the key by Popovici \& Buhl (2010). Detailed illustrations are given by Popovici \& Buhl (2010). The following notes are provided to improve the diagnosis of the female metasoma given in the original description of this species and to take account of telescoping of the apical gastral tergites, which varies naturally and can also be affected by the preservation techniques used. Numbers given are: range (arithmetic mean, \pm standard deviation) \{range for the type series\}.

\section{Diagnosis of female metasoma}

Ratio between length and width of metasoma 2.1-2.7 (2.2 \pm 0.17$)$ \{2.7-2.8\}; ratio between width and length of T1 3.0-4.5 $(3.4 \pm 0.5)\{3.6-5.0\}$; ratio between maximum and minimum width of T1 1.1-1.7 

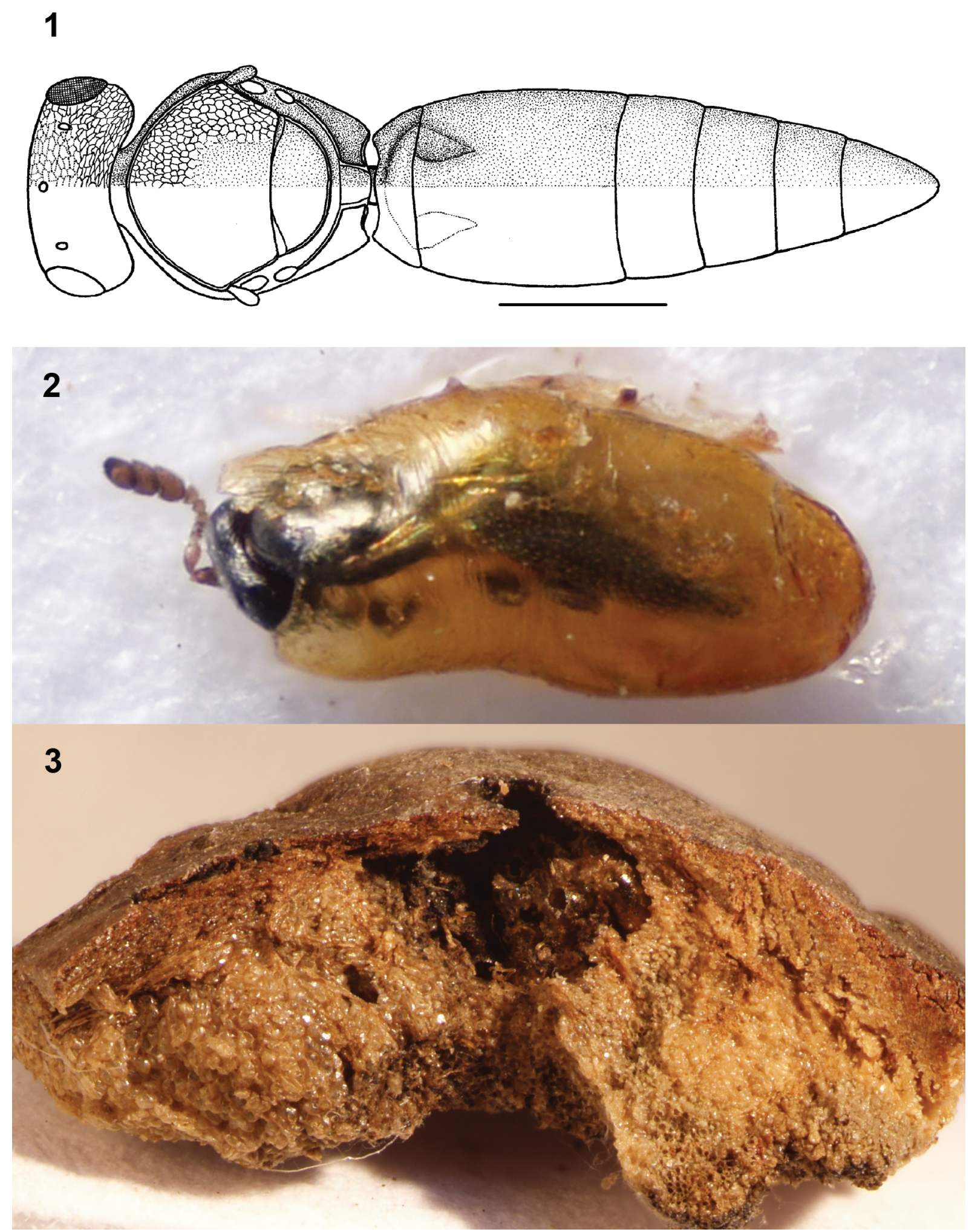

Figs 1-3. Fidiobia hispanica Popovici \& Buhl, 2010. 1. Dorsal habitus,,. 2. Host egg with half emerged +. 3. Fragment of old Andricus kollari gall showing cavity - a vacated cell of Synergus umbraculus containing beetle eggs, the true host of $F$. hispanica. Body length of wasp $c .0 .8 \mathrm{~mm}$. C Ovidiu Popovici. 
$(1.4 \pm 0.16)\{1.5-1.7\}$; ratio between length and width of $\mathrm{T} 20.8-1.1(0.9 \pm 0.1)\{1.0\}$; ratio between length of T2 and length of T1 3.3-6.5 (4.1 \pm 0.9$)\{4.8-5.0\}$; ratio between length of T2 and length of T3 $3.1-4.0(3.6 \pm 0.3)\{2.4\}$; ratio between maximum and minimum width of T2 1.2-1.5 (1.3 \pm 0.1$)\{1.2-$ $1.3\}$; ratio between length of T3 and length of T4 1-1.5 $(1.1 \pm 0.2)\{1.0-1.3\}$; ratio between maximum and minimum width of T3 1.1-1.3 (1.2 \pm 0.1$)\{1.1\}$; ratio between maximum and minimum width of T4 1.1$1.6(1.2 \pm 0.1)\{1.1-1.3\}$; T6 triangular, ratio between length of T6 and T5 1.7-2.8 (2.1 \pm 0.4$)\{1.3-1.5\}$.

\section{Material examined}

ENGLAND: London, Greenwich, Vanbrugh Pits, 16 + $\odot, 3 \hat{\jmath} \widehat{\partial}$, reared from a batch of beetle eggs in vacated Andricus lignicola (Hartig, 1840) gall on Quercus robur Linnaeus, 1753, gall collected 17 Jan. 2010, D. G. Notton; London, Greenwich, Vanbrugh Pits, TQ397771, 5 우요, reared from a batch of beetle eggs in a vacated cell of Synergus umbraculus (Olivier, 1791) in an old Andricus kollari (Hartig, 1843) gall on Quercus robur, gall collected 14 Mar. 2010, D. G. Notton (all BMNH).

\section{Distribution}

Genus and species recorded here as new to Britain. Previously recorded from Ireland by O'Connor et al. (2004, as F. synergorum) and from Spain and Ireland by Popovici \& Buhl (2010).

\section{Biology}

The genus Fidiobia contains more than a dozen species worldwide, of which seven are known from the Palaearctic. These wasps are endoparasitoids of beetle eggs, and consequently are very small, typically 0.6-1.3 mm, and rarely collected (Popovici \& Buhl 2010). Fidiobia hispanica was previously reared from the galls of Andricus lignicola by O'Connor et al. (2004), although the host remains were not located, and the host identity not confirmed. Spanish material was collected in a pine / juniper forest (Popovici \& Buhl 2010). In the present study two broods of $F$. hispanica were reared. The first was from a batch of beetle eggs found in a vacated gall of Andricus lignicola on Quercus robur. The host eggs were in a small irregular chamber at the base of the gall connected to the outside by a hole. There were at least 34 host eggs, 22 of which had been parasitised. (31 empty shells, 16 웅, $3 \hat{\delta} \delta^{\lambda}$ emerged, 3 unemerged). The second brood was reared from a batch of beetle eggs found in a vacated Synergus umbraculus cell in an old vacated Andricus kollari gall. In both cases the galls were old, previously vacated and of weathered appearance, and in both cases the hosts were beetle eggs and not the original inhabitants of the gall. There have been several other rearings of other Fidiobia species from oak galls (e.g., Vlug 1995; O'Connor et al. 2004), which may be explained the same way - Fidiobia reared from oak galls are not using Cynipidae or their inquilines or parasitoids as hosts; it is much more likely that they are attacking beetle eggs which have been laid in cavities in old oak galls. Furthermore, the possibility should be kept in mind that $F$. hispanica has no particular association with oak galls. Probably there is a sampling bias since many people rear oak galls, and there is currently no reason to suppose $F$. hispanica would not attack the same beetle eggs elsewhere, such as in bark crevices.

\section{Superfamily Platygastroidea Haliday, 1833 \\ Family Platygastridae Haliday, 1833 \\ Subfamily Scelioninae Ashmead, 1893}

\section{Genus Macroteleia Westwood, 1835}

Two species of Macroteleia were recorded from Britain by Notton (2006) and a third species is reported here. Since limited British material is currently available, further variation, particularly in colour, may be encountered. Provisional synonymy between M. minor and M. brevigaster is discussed below. Numerous Palaearctic species of Macroteleia are catalogued by Johnson (1992) and more have been described since (Kozlov \& Kononova 1987, 1990; Kononova \& Petrov 2003), although a number of 
old names have not been accounted for by recent authors, so some further synonymy may yet occur. The host relations of the British species are unknown, although other species of Macroteleia are solitary parasitoids of the eggs of bush crickets (Orthoptera: Tettigoniidae) (Muesebeck 1977).

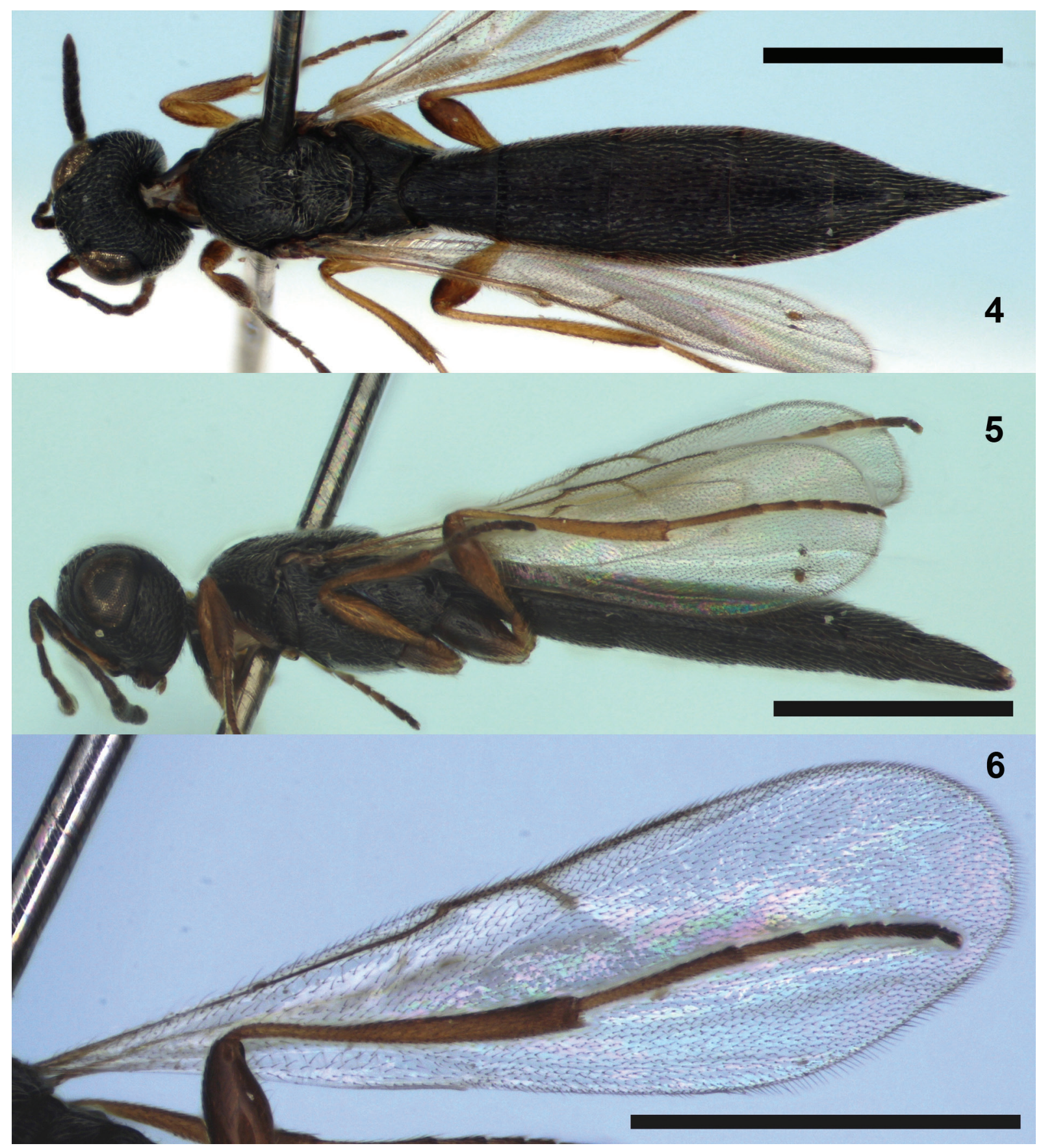

Figs 4-6. Macroteleia atrata Kozlov \& Kononova, 1987, ․ . 4. Dorsal habitus. 5. Lateral view. 6. Fore wing. Specimen number BMNH(E)968238. Scale bars all 1 mm. (C) Natural History Museum, London. 


\section{Key to females of British Macroteleia}

1. Gastral tergite 3 with lateral areas not defined; body less elongate (Fig. 10): exposed part of apical tergite 1.4-1.6 times as long as wide; postmarginal vein 1.4-1.6 times as long as marginal (body black; scape red-brown; legs red-brown, all coxae darkened)

Macroteleia brevigaster Masner, 1976

- Gastral tergite 3 with lateral area on each side defined by a longitudinal carina; body more elongate (Figs 4, 7): exposed part of apical tergite 2.2-2.6 times as long as wide; postmarginal vein 1.72.3 times as long as marginal

2. Gastral tergite 3 transverse, 1.2 times as wide as long; exposed part of apical tergite 2.2 times as long as wide; postmarginal vein 1.7 times as long as marginal (body black; scape dark brown with base orange-brown; legs orange-brown, mid and hind coxae darkened)

Macroteleia atrata Kozlov \& Kononova, 1987

- Gastral tergite 3 as long as wide; exposed part of apical tergite 2.6 times as long as wide; postmarginal vein 2.3 times as long as marginal (body dark brown to black above, yellow to yellow brown below; scape yellow-brown; legs including coxae yellow) ................Macroteleia bicolora Kieffer, 1908

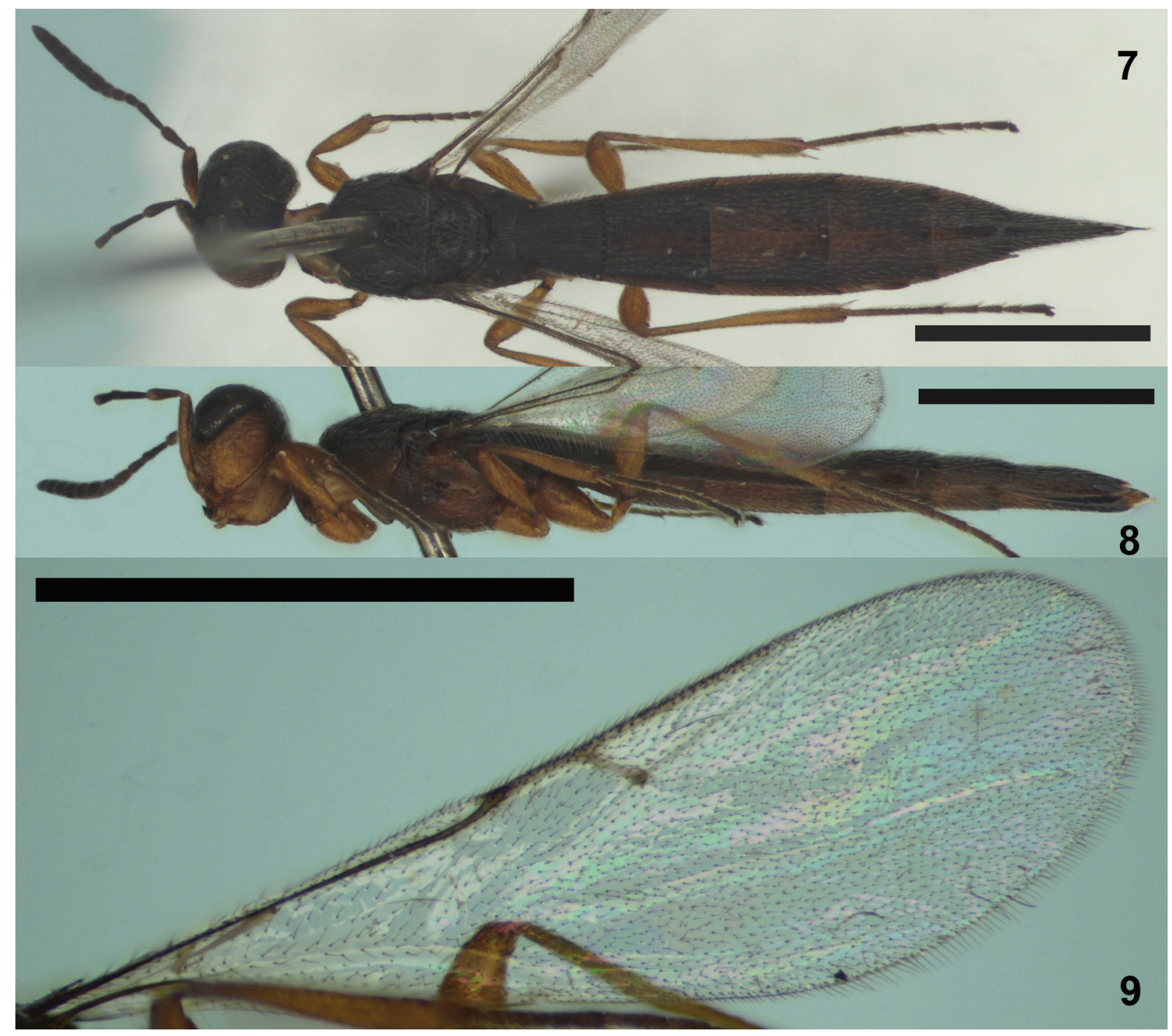

Figs 7-9. Macroteleia bicolora Kieffer, 1908, ㅇ. 7. Dorsal habitus. 8. Lateral view. 9. Fore wing. Specimen number BMNH(E)938241. Scale bars all 1 mm. (C) Natural History Museum, London. 
Macroteleia atrata Kozlov \& Kononova, 1987

Figs 4-6

\section{Remarks}

M. atrata was first recorded from Britain (Kent) by Notton (2006). Its distribution and favoured habitats are poorly known.

\section{Macroteleia bicolora Kieffer, 1908}

Figs 7-9

\section{Identification}

This specimen was identified to genus using the key by Masner (1980) but it did not agree with either of the two previously known British species of Macroteleia (Notton, 2006). The identity of the species was confirmed by the second author, who has examined the type and compared it to published descriptions (Kieffer 1908, 1914, 1926; Kozlov 1987; Kononova \& Kozlov 2008). Johnson (1992) catalogued numerous Palaearctic species of this genus and more have been described since (Kozlov \& Kononova 1987, 1990; Kononova \& Petrov 2003), although many of the older species have not been reinterpreted recently, and it is possible that the name M. bicolora will turn out to be a synonym.

\section{Material examined}

ENGLAND: Hants, Botley Wood, SU5409, +, 31 Jul. 2007, Malaise trap, K. J. Wheeler (BMNH).

\section{Distribution}

This species was originally described from Italy by Kieffer (1908), and its distribution includes: Northern Italy, Kazakhstan, Russia (Northern Caucasus), Ukraine (Kononova \& Kozlov 2008) and Denmark (Buhl 1999). It is recorded here as new to Britain.

\section{Biology}

The biology of this species is poorly known; however, the habitat at the Botley Wood Local Nature Reserve and SSSI is an extensive area of varied woodland, scrub and grassland with rides and ancient droveways of high conservation significance for invertebrates managed by Hampshire County Council/ Natural England.

Macroteleia brevigaster Masner, 1976

Figs 10-12

Apegus punctatus Kieffer, 1908: 150, 161 (preoccupied).

Macroteleia brevigaster Masner, 1976: 27 (replacement name for Ageus punctatus).

? Macroteleia minor Kozlov \& Kononova, 1987: 93, 95 (syn. nov.).

\section{Biology}

Combined records of Masner (1956) and Notton (2006) suggest that this species prefers dry grassland and dune habitats.

\section{Remarks}

M. brevigaster was first recorded from Britain (Devon and the Isle of Wight) by Notton (2006, as $M$. minor). It appears that $M$. brevigaster and $M$. minor are the same species, based on the interpretation of the former by Masner (1956, as Parapegus punctatus) and its similarity with the description of Kozlov \& Kononova's species. Unfortunately the types of neither A. punctatus nor M. minor could be 


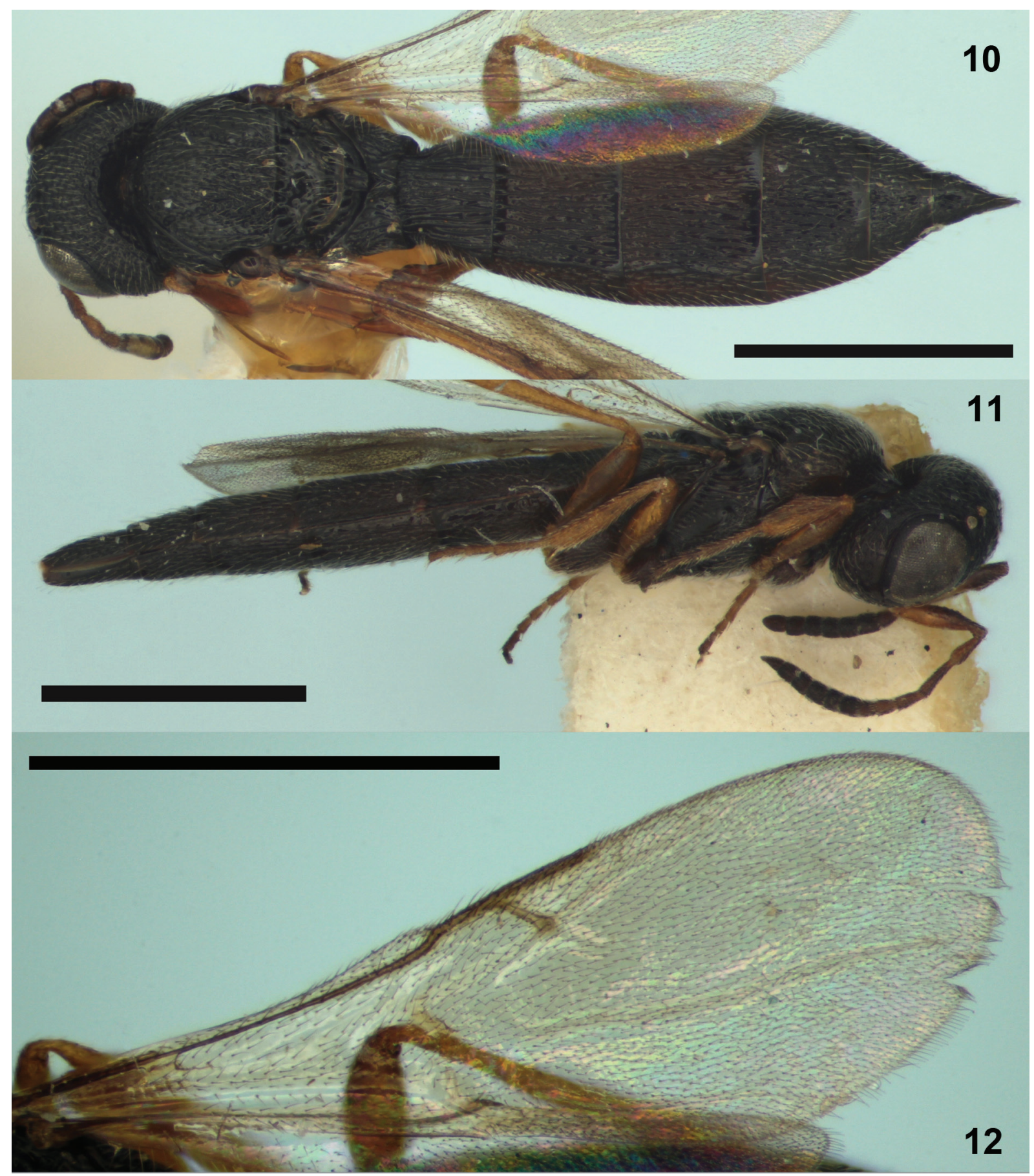

Figs 10-12. Macroteleia brevigaster Masner, 1976, ${ }$. 10. Dorsal habitus. 11. Lateral view. 12. Fore wing. Specimen numbers BMNH(E)968239 and BMNH(E)968240. Scale bars all $1 \mathrm{~mm}$. (C) Natural History Museum, London. 
examined, so the new synonymy proposed here is provisional. The new synonymy suggests that the distribution of this species is much wider: Bulgaria (Kononova \& Petrov 2003, as M. minor); Czech Republic and Slovakia (Masner 1956, as P. punctatus); England and the Channel Islands (Notton 2006, as M. minor); Hungary (Kozlov 1978, as P. punctatus); Northern Italy (Kieffer 1908, as A. punctatus); Romania (Popovici 2007; Fabritius \& Popovici 2007, as M. minor); and Ukraine (Kozlov \& Kononova 1987, as M. minor).

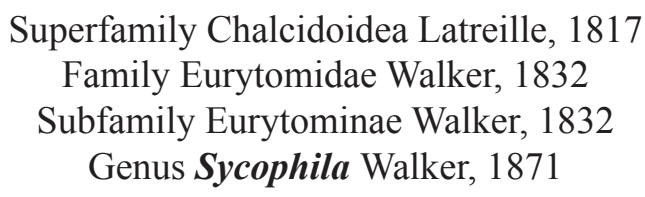

Sycophila binotata Fonscolombe, 1832

\section{Identification}

Figs 13-14

This species keyed easily in Zerova (1978 - as Eudecatoma binotata) and agrees with the concept of Z. Bouček and M. Graham (Graham 1992), based on the lectotype designated by Graham, and specimens determined by Bouček and Graham in BMNH, and was confirmed by R. R. Askew (pers. comm.). The species is highly distinctive among European Sycophila in having two dark fasciae on each fore wing.

\section{Material examined}

ENGLAND: London, Fulham, Imperial Wharf, TQ263765, 9 , ex gall of Aphelonyx cerricola on Quercus suber, gall coll. 21 Mar. 2010, M. Barclay, BMNH(E)969429; $ᄋ$, same data, except gall coll. 26 Sep. 2011, BMNH(E)969430.

\section{Distribution}

S. binotata has a widespread distribution in southern Europe including Spain, France, Italy, and the Balkans (Noyes 2013; Askew et al. 2013), although it was not recovered during a recent survey of parasitoids of A. cerricola (Giraud, 1859) in central Europe (Melika et al. 2002). It is recorded here as new to Britain.

\section{Biology}

British material of S. binotata was reared from the galls of Aphelonyx cerricola collected from Quercus suber L. The exact insect host was not established, since other inquiline and parasitoid Hymenoptera were also present as well as the gall causer; however, it has apparently not been reared from galls of Aphelonyx previously (Melika et al. 2002; Askew et al. 2013) and is normally an oligophagous endoparasitoid of Plagiotrochus spp. (Cynipidae) on evergreen species of Quercus L. of sections Cerris Loudon and Ilex Loudon (Gómez et al. 2013). The history of the Quercus suber trees which hosted the British S. binotata is of some interest - they were planted as well-established saplings during the winter of 2005-2006, and their origin is most likely to have been Italy; novel Coleoptera found in association with these trees are likely to have come from Italy and an Italian coin was found in the soil around their roots (M. V. L. Barclay pers. comm.), so it seems likely that the S. binotata was imported with the trees direct from Italy and has survived for several generations in Britain.

\section{Remarks}

If, as seems likely, S. binotata was imported together with its gall wasp host and host tree, this is of considerable interest for studies of the recruitment of parasitoids of invasive gall wasps in the UK. Some previous studies of the parasitoids of invasive gall wasps in the UK have considered two main methods of recruitment, either recruitment from an existing pool of native parasitoids, or that 


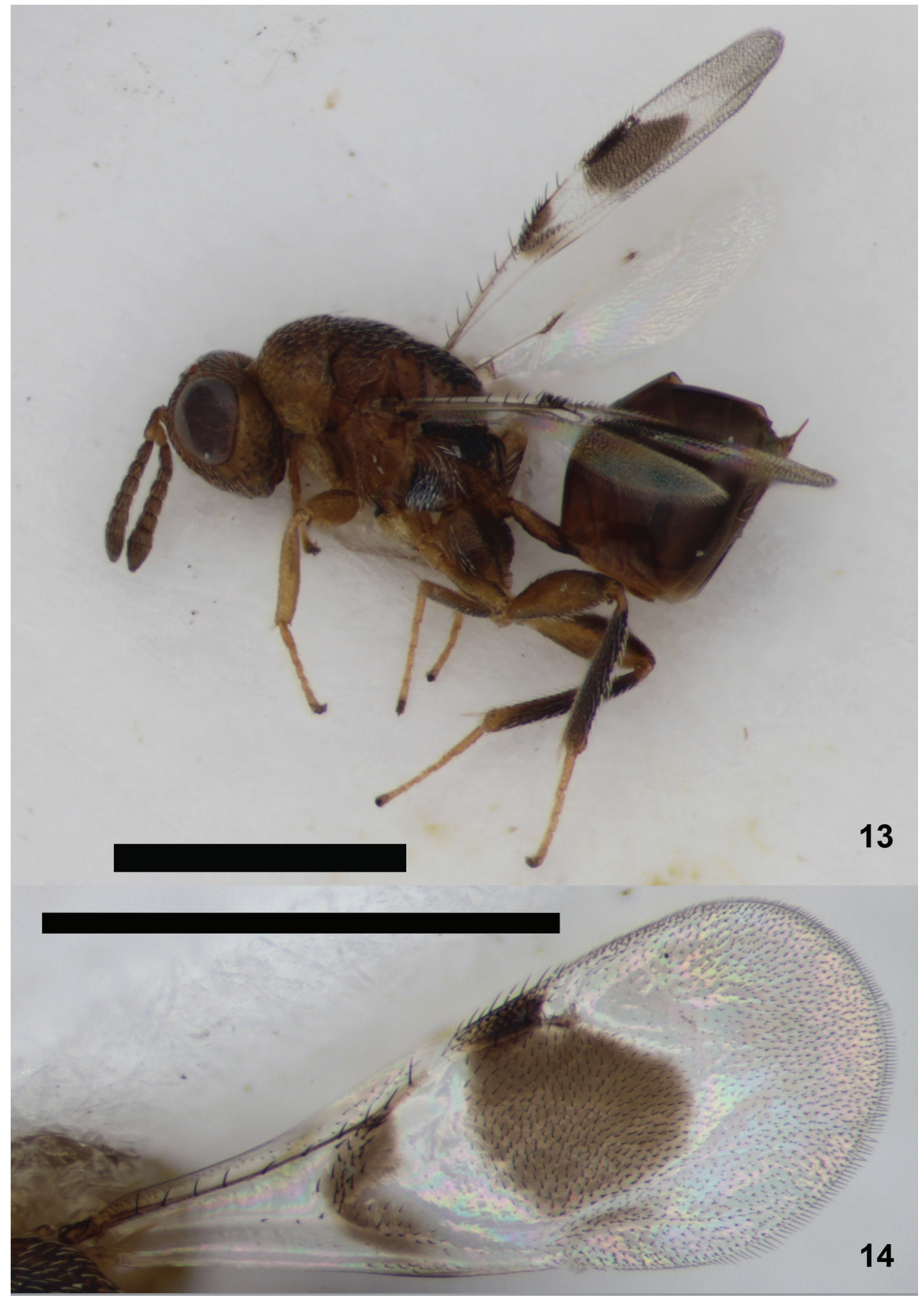

Figs 13-14. Sycophila binotata Fonscolombe, 1832, ๆ. 13. Lateral habitus. 14. Fore wing. Specimen number BMNH(E)969430. Scale bars both $1 \mathrm{~mm}$. C Natural History Museum, London. 
populations of parasitoids might pursue host gall wasps as they spread continuously across Europe, the former appearing more likely (Schönrogge et al. 2006, 2011). However, the presence of the previously non-British S. binotata in London, in circumstances where good-sized trees were imported, raises a third, more radical possibility, that recruitment is not necessary when parasitoids are not lost by their cynipid hosts. Oak trees could be imported through the horticulture trade with a community of gall wasps and parasitoids more or less intact; this would of course be much faster than the unassisted, or partially assisted, spread of both gall wasp and parasitoid. It is of course possible that other parasitoids have also been imported in this way; such introductions may be easily overlooked, especially where the same species already occurs in Britain. Without historical evidence of the circumstances of importation of host gall wasps, such instances could have been misinterpreted as recruitment from the existing pool of native parasitoids, so caution is needed when interpreting recruitment studies of such imported gall wasps. Given the numbers of good-sized oaks used in the UK for prestigious building developments and parks, in particular Quercus ilex L. and its associated gall wasp species, e.g., Plagiotrochus Mayr, 1881, the potential for other parasitoids to be introduced in this way is clear.

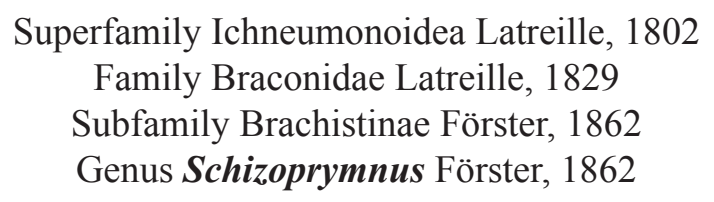

Schizoprymnus collaris (Thomson, 1874)

Figs 15-25

Sigalphus collaris Thomson, 1874: 557

Triaspis collaris - auct.

\section{Identification}

Schizoprymnus collaris keys readily to genus using the key to subfamily and notes given by Shaw \& Huddleston (1991) and also the key to genera by Tobias et al. (1995). There is no key specifically to British species of Schizoprymnus, and this species will not run in the key to European Schizoprymnus by Tobias et al. (1995), which erroneously includes $S$. collaris in the key to Triaspis Haliday, 1838. However, the British specimen has been directly compared with the lectotype of $S$. collaris and agrees well. S. collaris is an aberrant species when compared to other Schizoprymnus and may be distinguished from other British species in this genus as follows: frontal crest absent, at most a blunt ridge; antennal scrobes with regular transverse striations (Fig. 16); lateral carina of scutellum absent (Fig. 18); sutures of carapace weakly developed but present laterally, the first suture perpendicular to the margin, the second suture directed obliquely backwards (Fig. 17); third tergite largely convex with only weak concavity at extreme apex and deep medial incision in posterior margin to accommodate ovipositor (Fig. 19); apical margin of carapace not turned under, so that sternites are not concealed; ovipositor extending beyond apex of carapace by 1.2-1.3 times length of carapace (Fig. 15); pronotum and mesonotum extensively marked with red and hind femur red (Fig. 17).

\section{Material examined}

ENGLAND: Wiltshire, Porton Down, The Breck, 51'8'30.9'N 1'38'23.3”W, $105 \mathrm{~m}$, chalk heath, meadow / scrub, ㅇ, 3 Aug. 2012, D. G. Notton, BMNH(E)2012-120, BMNH(E)968229 (Natural History Museum, London).

GERMANY: + , pre-1859, M. Ruthe coll., [BMNH(E)18]59.101 (BMNH).

SWEDEN: [Skåne, Båstad], , , Thomson coll., lectotype (Entomological Collection of Lund University). 


\section{Distribution}

S. collaris is rare in collections but has previously been recorded from France, Germany, Lithuania, The Netherlands and Sweden (Thomson 1874; van Achterberg 2009), but is not included in the recent British checklists of Fitton et al. (1978) or Broad et al. (2012) and so is recorded here as new for Britain.

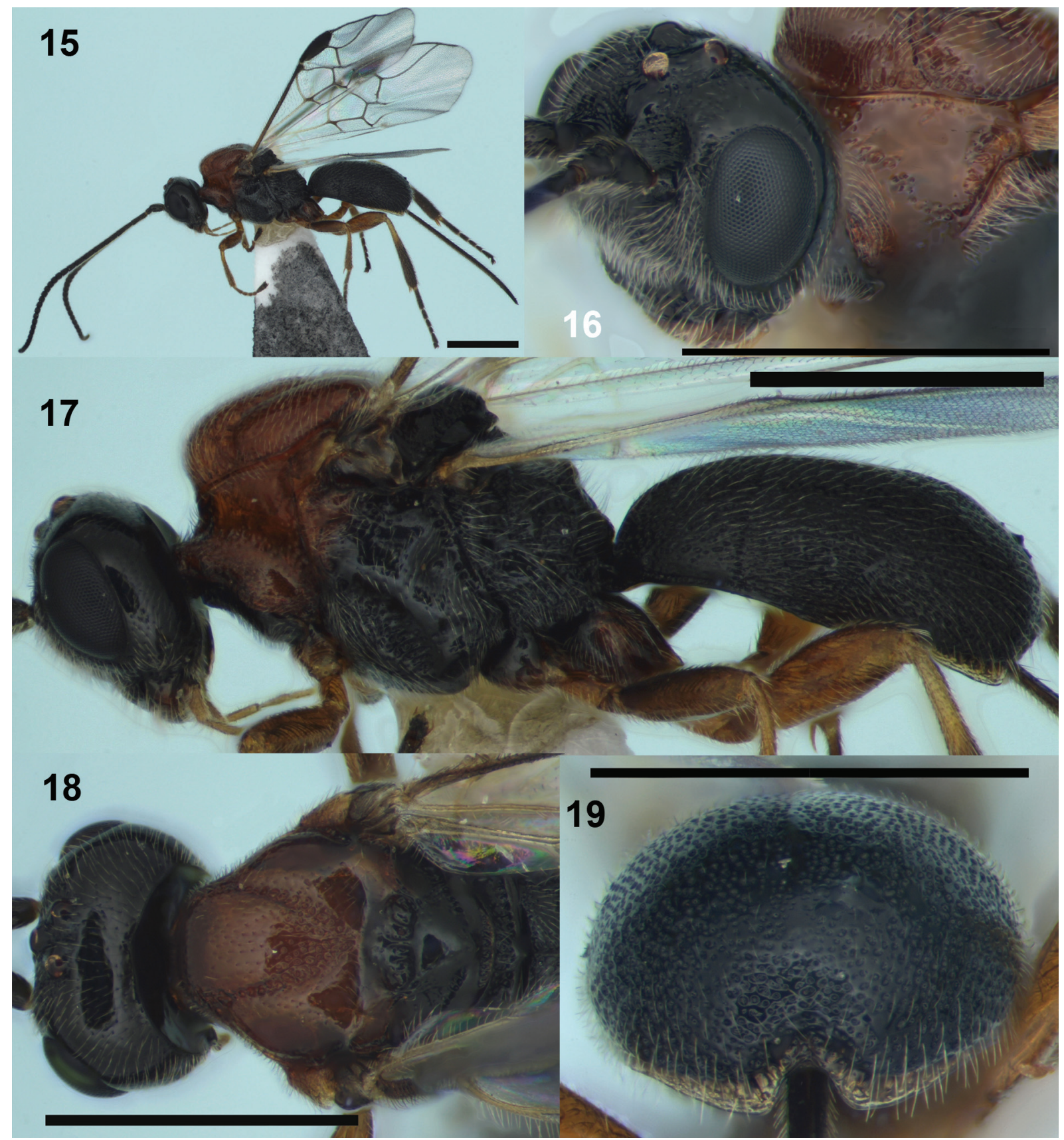

Figs 15-19. Schizoprymnus collaris (Thomson, 1874), ㅇ BMNH(E)968229. 15. Lateral habitus. 16. Head. 17. Lateral body. 18. Dorsal head. 19. Mesosoma, posterior tergite 3. Scale bars all $1 \mathrm{~mm}$. (C) Natural History Museum, London. 


\section{Biology}

Host relations of S. collaris are unknown; however, other Schizoprymnus species are known to be koinobiont egg-larval parasitoids of weevils (Curculionidae), seed beetles (Chrysomelidae: Bruchinae) and tumbling flower beetles (Mordellidae) (Shaw \& Huddleston 1991; Belokobylskij \& Maetô 2007; Güçlü \& Özbek 2011). The habitat, where the English specimen was collected is a rare herb-rich chalk heath habitat with Juniperus communis L., Betula L. and small amounts of other scrub (English Nature 1999).

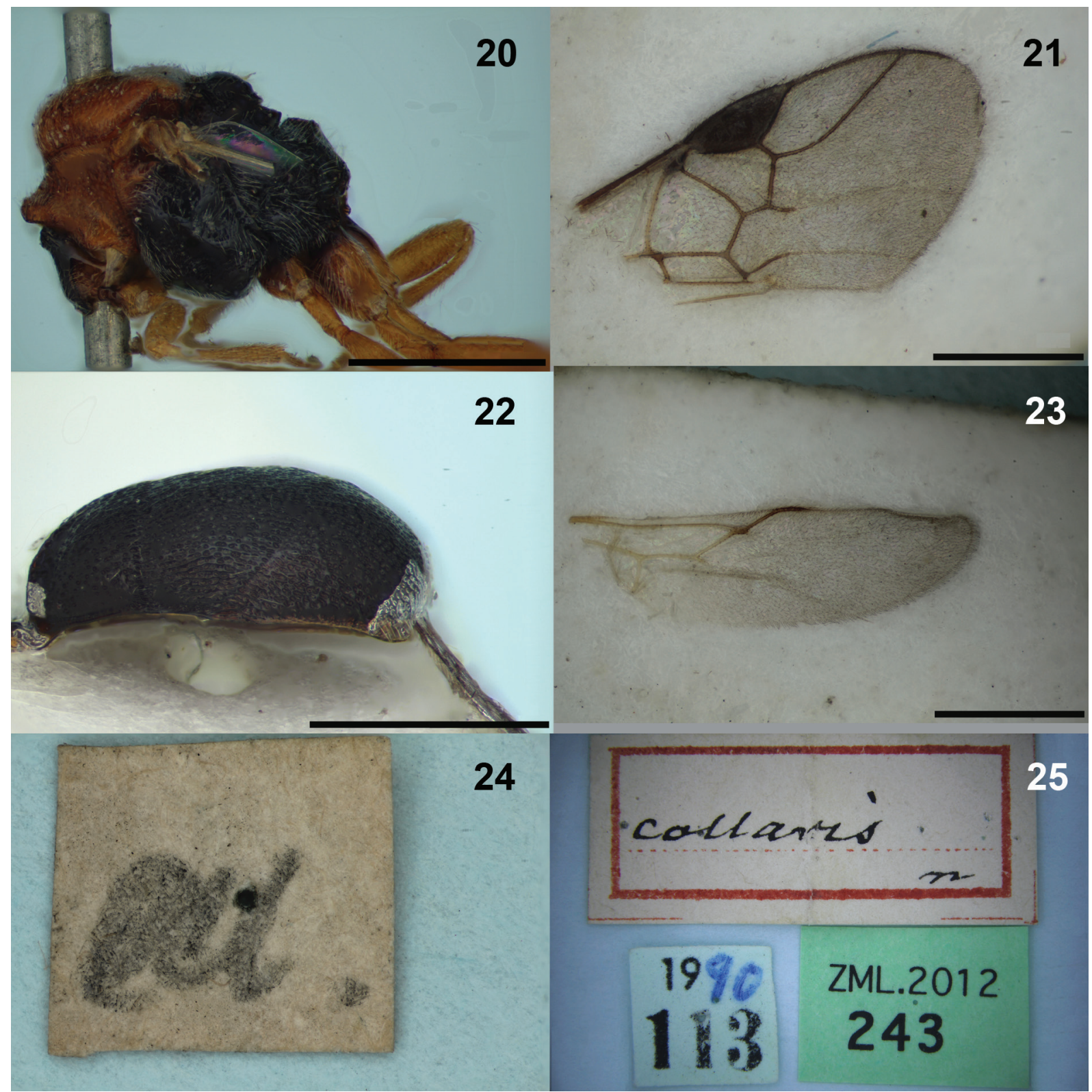

Figs 20-25. Schizoprymnus collaris (Thomson, 1874), + , lectotype. 20. Lateral mesosoma. 21. Fore wing. 22. Lateral metasoma. 23. Hind wing. 24. Thomson's locality label. 25. Other labels. Scale bars all $1 \mathrm{~mm}$. (C) Natural History Museum, London. 


\section{Remarks}

A syntype was examined from the Thomson Collection, at the University of Lund, and is designated here as the lectotype in order to remove any possible ambiguity about the application of this name. S. collaris was previously placed in Schizoprymnus by Telenga (1941: 351) and while recently it has been considered a Triaspis, its position in Schizoprymnus is confirmed here.

Superfamily Chrysidoidea Latreille, 1802

Family Bethylidae Förster, 1856

Subfamily Epyrinae Kieffer, 1914

Genus Laelius Ashmead, 1893

One species of this genus, Laelius microneurus, was reported previously from Britain and was keyed by Perkins (1976). Recent taxonomic work has shown that this species should be called L. femoralis (see below for discussion and synonymy). A second species, L. pedatus, is newly reported here from Britain. The two species may be identified from the key by Vikberg \& Koponen (2005); a simplified key is presented here for the British species.

\section{Key to females of British Laelius}

1. Stigmal vein straight or almost straight, barely or not widened apically; pterostigma brown, slightly darker than basal vein, and without a seta which is longer than the nearby setae on the costal vein; apex of costal cell with several short setae; propodeum with discal longitudinal carinae slightly converging posteriorly; disc of fore wing hyaline (normally found outdoors)

Laelius femoralis (Förster, 1860)

- Stigmal vein curved and apically broadened; pterostigma as pale as basal vein and with dorsal seta which is longer than the nearby setae on the subcostal vein; apex of costal cell with $0(-1)$ small setae; propodeum with discal longitudinal carinae slightly diverging posteriorly, furthest apart at about posterior $2 / 3$; disc of fore wing infuscate (normally found indoors) .... Laelius pedatus (Say, 1836)

Laelius pedatus (Say, 1836)

Figs 26-28

\section{Identification}

This species was provisionally identified by John Burn and confirmed by Jeroen de Rond; it may be identified using the key by Vikberg \& Koponen (2005) covering Scandinavian species of Laelius; they provided a redescription of both sexes and illustrated the wing venation and propodeum of the female and genitalia and apical sclerites of the male. Vikberg \& Koponen discussed the steps they took, in the absence of the original type material, to ensure that their interpretation was consistent with previous works such as Evans (1978). The specimens mentioned as plesiotype and plesiallotype by Evans (1978) have no type status as these terms are not recognised by the ICZN; they are merely the specimens on which he based his redescription. The recent specimens mentioned by Vikberg \& Koponen (2005) as paratypes are not paratypes; this is an error, since Say's type(s) are lost.

\section{Material examined}

ENGLAND: London, Lewisham, TQ388757, + 19 May 2013, in kitchen, D. G. Notton; London, The Natural History Museum, Entomology Department, TQ265790, q, Jul. 1996, A. Polaszek; London, The Natural History Museum, Palaeontology Department, ICZN Secretariat Office, TQ267790, +, 2 Oct. 2008, walking across desk, D. G. Notton; London, Streatham Hill, TQ304725, §ૈ, 7 Jul. 2006, G. Broad;

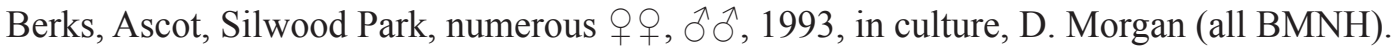


THE NETHERLANDS: Leiden University,, , cultured on Trogoderma angustum (Solier, 1849) (wasps from this culture originated from Madison University, Wisconsin, U.S.A.), P. Mayhew (BMNH).

\section{Distribution}

Originating from the New World: Canada, United States of America, Mexico and Brazil (Gordh \& Móczár 1990). More recently recorded from Europe: The Netherlands (Heitmans 1998), Finland (Vikberg \& Koponen 2005) and now Britain. L. pedatus was kept in culture in Britain by David Morgan at Imperial College (probably the Imperial College field station at Silwood Park near Ascot, Berkshire, U.K.) for some time from at least 1993 (Mayhew 1998), and the possibility of escapees cannot be excluded as a source of the British specimens reported here. Morgan's culture originated from a culture kept by the United States Department of Agriculture in Hoboken, New Jersey (Morgan \& Cook 1994). An alternative possibility is that wasps were introduced from mainland Europe, where free-living wasps have been present since at least 1987 (Vikberg \& Koponen 2005).

\section{Biology}

L. pedatus is a parasitoid of the larvae of various species of carpet beetles (Coleoptera, Dermestidae), including those which are pests of stored products and museum collections. In Europe the wasp has previously only been found indoors (Gordh \& Móczár 1990; Heitmans 1998; Vikberg \& Koponen 2005), as were the British specimens.

\section{Remarks}

The presence of $L$. pedatus in museums is a matter for concern not because of any problem caused by the wasp itself, but because it may indicate the presence of long standing dermestid infestations upon which they prey. Since the adults of this wasp are quite mobile they might be found on the sticky traps used for museum pest monitoring. Anyone encountering bethylid wasps in these situations is invited to submit the specimens to the senior author in order that the spread of this species can be monitored. One of the localities given above, the old Entomology Building at the Natural History Museum, London, has been demolished and replaced by the new Darwin Centre, which has much improved environmental control and pest management.

Laelius femoralis (Förster, 1860)

Allepyris microneurus Kieffer, 1906: 416-417 (syn. nov.).

Allepyris nigricrus Kieffer, 1906: 417 (syn. nov.).

\section{Identification}

Material (previously identified as L. microneurus) in BMNH was reidentified according to the key by Vikberg \& Koponen (1995) to confirm the presence of L. femoralis in Britain.

\section{Material examined}

ENGLAND: Berkshire, Silwood Park, 18 Aug. 1975, dead spruce, O.W. Richards, B.M.1967-510; Kent, Beckenham, 9 Jul. 1972, D.E. Kimmins; Surrey, Kew, 17 Jul. 1977, from Crataegus Linnaeus, 1753, specimen number 15,576, V.F. Eastop (all BMNH).

\section{Remarks}

Berland (1928) studied the female types of L. macrocerus and L. nigricrus (in Muséum National d'Histoire Naturelle, Paris) and could not find any difference between them, so he synonymised the two names. It was first suggested that $L$. microneurus was a synonym of $L$. femoralis by de Rond (in Vikberg $\&$ Koponen 2005) and from subsequent examination of all the types, including the female neotype of $L$. 


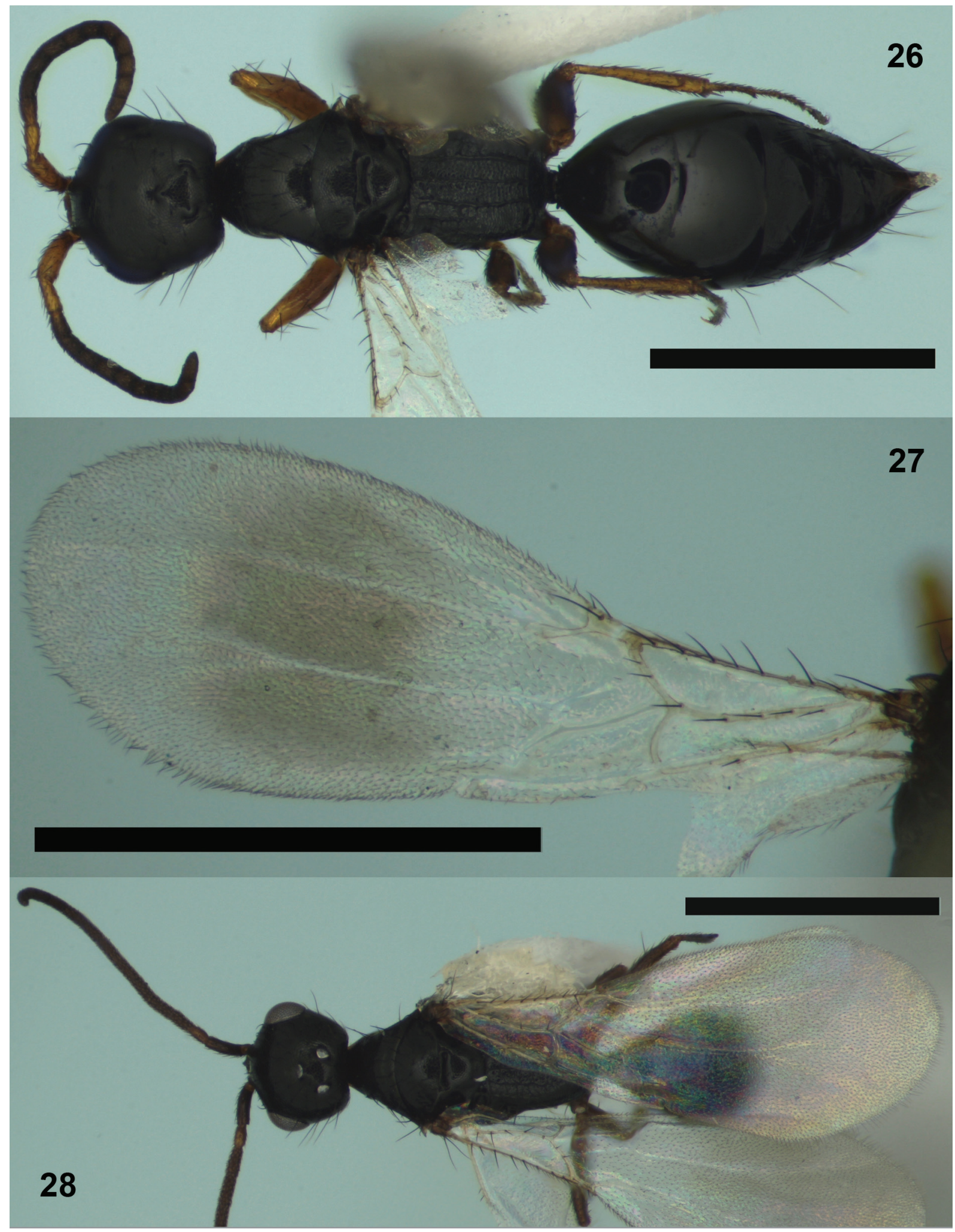

Figs 26-28. Laelius pedatus (Say, 1836), 26-27. $\odot$, specimen number BMNH(E)968242. 26. Dorsal habitus. 27. Fore wing. 28. O’, specimen number BMNH(E)968243, dorsal habitus. Scale bars all $1 \mathrm{~mm}$. (C) Natural History Museum, London. 
femoralis (in the Nationaal Natuurhistorisch Museum, Leiden), de Rond has come to the conclusion that both $L$. microneurus and $L$. nigricrus are junior synonyms of $L$. femoralis. This means that the species in Britain referred to as L. microneurus by Perkins (1976) should now be called L. femoralis.

\section{Discussion}

Knowledge of the composition of the British Hymenoptera fauna is essential for the purposes of biological studies requiring accurate identifications, and their applications, including conservation of native species, and the monitoring of faunal change. It is hoped that this paper will be a useful contribution to the ongoing process of documenting British Hymenoptera and stimulate further study of these fascinating creatures.

\section{Acknowledgements}

Thanks are due to: Barry S. Duffin (Hampshire County Council), K. J. Wheeler and Richard Dickson for the collection and donation of M. bicolora; Cassie Herschel-Shorland, Gavin Broad (BMNH) and Andrew Polaszek (BMNH) donated or collected specimens of Laelius pedatus; Christer Hansson (Entomological Collection of Lund University) loaned the type of Schizoprymnus collaris; Maxwell V. L. Barclay (BMNH) provided the galls containing Sycophila binotata; Richard R. Askew confirmed the identity of Sycophila binotata; Sergey Belokobylskij (Zoological Institute, Russian Academy of Sciences, St. Petersburg) provided reprints; Stuart J. Corbett and Sarah Atkinson (Defence Science \& Technology Laboratory, Ministry of Defence, Porton Down) arranged access to Porton Down; Andrew Polaszek reviewed the manuscript.

\section{References}

Askew R.R., Melika G., Pujade-Villar J., Schönrogge K., Stone G.N. \& Nieves-Aldrey J.L. 2013. Catalogue of parasitoids and inquilines in cynipid oak galls in the West Palaearctic. Zootaxa 3643: 1-133. http://dx.doi.org/10.11646/zootaxa.3643.1.1

Belokobylskij S.A. \& Maetô K. 2007. New subgenus of the genus Schizoprymnus (Hymenoptera: Braconidae) from Japan, having a unique abdominal carapace structure. Entomological Science 10 (2): 171-178. http://dx.doi.org/10.1111/j.1479-8298.2007.00211.x

Berland L. 1928. Hyménoptères Vespiformes II (Eumenidae, Vespidae, Masaridae, Bethylidae, Dryinidae, Embolemidae). Faune de France 19: 1-206.

Broad G.R., Shaw M.R. \& Godfray H.C.J. 2012. Checklist of British and Irish Braconidae (Hymenoptera). http://www.nhm.ac.uk/resources-rx/files/braconidae-checklist-for-web-34139.pdf [accessed 27 Nov. 2012].

Buhl P.N. 1999. Tillaeg til fortegnelsen over Danmarks proctotruper (Hymenoptera, Proctotrupoidea s.1.) 2. del: Scelionidae, Platygastridae, Megaspilidae og Ceraphronidae [Supplement to the list of Danish Proctotrupoidea sensu lato. Part 2: Scelionidae, Platygastridae, Megaspilidae and Ceraphronidae]. Flora og Fauna 105 (1): 9-13.

Buhl P.N. \& Notton D.G. 2009. A revised catalogue of Platygastridae of the British Isles (Hymenoptera: Platygastroidea). Journal of Natural History 43: 1651-1703. http://dx.doi. org/10.1080/00222930902993732

English Nature. 1999. Porton Down: Site of Special Scientific Interest (SSSI) notified under section 28 of the Wildlife and Countryside Act 1981 as amended. http://www.sssi.naturalengland.org.uk/citation/ citation photo/1003140.pdf [accessed 28 Nov. 2012]. 
Evans H.E. 1978. The Bethylidae of America north of Mexico. Memoirs of the American Entomological Institute 27: 1-332.

Fabritius K. \& Popovici O. 2007. A catalogue of Scelionidae from Romania (Hymenoptera, Platygastroidea). Entomologica Romanica 12: 133-161. http://er.lepidoptera.ro/12 2007/ER12200715 Fabritius Popovici.pdf

Fitton M.G., Graham M.W.R. de V., Bouček Z.R.J., Fergusson N.D.M., Huddleston T., Quinlan J. \& Richards O.W., 1978. A Checklist of British Insects 4. Hymenoptera. Handbooks for the Identification of British Insects 11 (4), Royal Entomological Society, London.

Gómez J.F., Nieves-Aldrey J.L. \& Stone G.N. 2013. On the morphology of the terminal-instar larvae of some European species of Sycophila (Hymenoptera: Eurytomidae) parasitoids of gall wasps (Hymenoptera: Cynipidae). Journal of Natural History 47: 2937-2960. http://dx.doi.org/10.1080/002 22933.2013.791937

Gordh G. \& Móczár L., 1990. A catalog of the world Bethylidae. Memoirs of the American Entomological Institute 46: 1-364.

Graham M.W.R. de V. 1992. Hymenoptera collections of Boyer de Fonscolombe, with an account of his work and a description of the natural features of his estate. Journal of Natural History 26: 1089-1111. http://dx.doi.org/10.1080/00222939200770631

Güçlü C. \& Özbek H. 2011. A contribution to the knowledge of the subfamily Brachistinae (Hymenoptera: Braconidae) in Turkey. Journal of the Entomological Research Society 13 (3): 15-26.

Heitmans W.R.B. 1998. Laelius pedatus: een nieuwe, exotische platwesp uit gebouwen in Nederland. Bzzz. Nieuwsbrief sectie Hymenoptera van de Nederlandse Entomologische Vereniging 8: 14-16.

Johnson N.F. 1992. Catalog of world species of Proctotrupoidea, exclusive of Platygastridae (Hymenoptera). Memoirs of the American Entomological Institute 51: 1-825.

Kieffer J.J. 1908 Revision des Scelionidae (Hyménoptères). Annales de la Société Scientifique de Bruxelles 32: 111-250.

Kieffer J.J. 1914. Proctotrypidae (3e partie). In: André E. (ed.) Species des Hyménoptères d'Europe et d'Algérie 11: 305-448. Private edition, Beaune.

Kieffer J.J. 1926. Scelionidae. Das Tierreich 48, Walter de Gruyter \& Co, Berlin.

Kononova S.V. \& Kozlov M.A. 2008. [Scelionids of the Palaearctic (Hymenoptera, Scelionidae): Subfamily Scelioninae]. Saint Petersburg, Tovarishchestvo Nauchnykh Izdanii KMK.

Kononova S.V. \& Petrov S. 2003. New species of egg parasites of the family Scelionidae (Hymenoptera, Proctotrupoidea) in the Palaearctic fauna. Zoologicheskii Zhurnal 82: 603-612.

Kozlov M.A. \& Kononova S.V. 1987. [New Palaearctic species of the genus Macroteleia Westwood, 1835 (Hymenoptera, Scelionidae).]. In: Ler P. A. \& Storozheva N. A. (eds) Novy e Dannye po Sistematike Nasekomykh Dal'nego Vostoka [New Data on the Systematics of Insects of the Far East]: 93-101. Academy of Sciences of the USSR, Far East Branch, Biology \& Soil Institute, Vladivostok.

Kozlov M.A. \& Kononova S.V. 1990. Stselionidy fauny SSSR (Hymenoptera, Scelionidae, Scelioninae). Opredeliteli po Faune SSSR 161: 1-344.

Kozlov M.A. 1987. Scelionidae. In: Medvedev G.S. (ed.) Keys to the Insects of the European Part of the USSR vol. 3(2) Hymenoptera: 1110-1179. Keys to the Fauna of the USSR 120, Nauka Publishers, Leningrad. 
Kozlov M.A., 1978. [Identification of the insects of the European part of the USSR. Hymenoptera: Scelionidae]. Opredeliteli po Faune SSSR 3(2): 608-646.

Masner L., 1956. Bemerkungen zur Systematik der Gattung Parapegus Kieffer, 1908 (Hym. Scelionidae). Zoologischer Anzeiger 157 (11/12): 234-239.

Masner L. 1980. Key to genera of Scelionidae of the Holarctic region, with descriptions of new genera and species (Hymenoptera: Proctotrupoidea). Memoirs of the Entomological Society of Canada 113: 1-54. http://dx.doi.org/10.4039/entm112113fv

Masner L. \& Huggert L. 1989. World review and keys to genera of the subfamily Inostemmatinae with reassignment of the taxa to the Platygastrinae and Sceliotrachelinae (Hymenoptera: Platygastridae). Memoirs of the Entomological Society of Canada 147: 1-214. http://dx.doi.org/10.4039/entm121147fv

Mayhew P.J. 1998. Offspring size-number strategy in the bethylid parasitoid Laelius pedatus. Behavioral Ecology 9 (1): 54-69.

Melika G., Csóka G., Stone G.N., Schönrogge K. 2002. Parasitoids reared from galls of Aphelonyx cerricola (Giraud, 1859) and Synophrus politus Hartig, 1843 (Hymenoptera, Cynipidae). Cecidology 17(2): 76-80.

Morgan D.J.W. \& Cook J.M. 1994. Extremely precise sex ratios in small clutches of a bethylid wasp. Oikos 71: 423-430. http://www.jstor.org/stable/3545830

Muesebeck C.F.W. 1977. The parasitic wasps of the genus Macroteleia Westwood of the New World (Hymenoptera, Proctotrupoidea, Scelionidae). United States Department of Agriculture Technical Bulletin 1565: 1-57.

Notton D.G. 2006. Genus group taxa of Platygastroidea (Hymenoptera: Scelionidae \& Platygastridae) new to Britain. Entomologist's Monthly Magazine 142: 189-232.

Noyes J.S. 2013. Universal Chalcidoidea Database. http://www.nhm.ac.uk/chalcidoids [accessed 8 Jan. 2014].

O’Connor J.P., Nash R., Notton D. G. \& Ferguson N. D. M. 2004. A catalogue of the Irish Platygastroidea and Proctotrupoidea (Hymenoptera). Occasional Publication of the Irish Biogeographical Society 7: $1-110$.

Perkins J.F. 1976. Hymenoptera: Bethyloidea (excluding Chrysididae). Handbooks for the Identification of British Insects. VI (3a): 1-38. Royal Entomological Society, London.

Popovici O. 2007. Biodiversitatea familiilor scelionide şi platigastride (Hymenoptera: Scelionidae, Platygastridae) din estul României. Teză de Doctorat. PhD Thesis, Iasi University, Roumania. [Biodiversity of scelionids and platygastrids from Eastern Romania]

Popovici O.A. \& Buhl P.N. 2010. The West Palaearctic species of Fidiobia Ashmead, 1894 (Hymenoptera: Platygastroidea). Journal of Natural History 44: 1131-1164. http://dx.doi. org $/ 10.1080 / 00222931003632740$

Schönrogge K., Begg T., Williams R., Melika G., Randles Z. \& Stone G. N. 2011. Range expansion and enemy recruitment by eight alien gall wasp species in Britain. Insect Conservation and Diversity 5 (4): 298-311.

Schönrogge K., Randle Z., Hateley S., Begg T., Aebi A. \& Stone G. 2006. Cynipid invasions throughout Europe and within the UK. Cecidology 21(2): 73-75.

Shaw M.R. \& Huddleston T. 1991. Classification and biology of braconid wasps. Handbooks for the Identification of British Insects 7(11): 126. Royal Entomological Society, London. 
Telenga N.A. 1941. Insectes Hyménoptères. Fam. Braconidae: sous-fam. Braconinae (cont.) et Sigalphinae. In: Sernov S.A. \& Stackelberg A.A. (eds) Faune de l'URSS 5(3): xvii + 466.

Thomson C.G. 1874. XXIV. Öfversigt af Sveriges Sigalpher. Opuscula Entomologica 6: 553-588.

Tobias V.I., Belokobylskij S.A. \& Kotenko A.G. 1995. Family Braconidae. In: Medvedev G.S. (ed.) Keys to the Insects of the European Part of the USSR 3(4). Hymenoptera, Braconidae. Keys to the Fauna of the USSR 145, Science Publishers, Lebanon, New Hampshire.

Van Achterberg C. 2009. Schizoprymnus collaris (Thomson, 1874). Fauna Europaea: Braconidae (online checklist of European species excluding Caucasus). Fauna Europaea version 2.0 http://www. faunaeur.org/full_results.php?id=340034 [accessed 7 Nov. 2012]

Vikberg V. \& Koponen M. 2005. Contribution to the taxonomy of the Palaearctic species of the genus Laelius Ashmead, mainly from Finland and Sweden (Hymenoptera: Chrysidoidea: Bethylidae). Entomologica Fennica 16 (1): 23-50.

Vlug H.J. 1995. Catalogue of the Platygastridae (Platygastroidea) of the World (Insecta: Hymenoptera). Hymenopterorum Catalogus 19: 1-168.

Zerova M.D. 1978. [Eurytomidae]. In: Medvedev G.S. (ed.) Opredilitel' Nasekomykh Evropeiskoi Chasti SSSR: Pereponchatokrylye, Vtoria Chasti'3(2): 328-358. Nauka Publishers, Leningrad. [English translation: Sharma, B.R. 1987. Keys to the Insects of the European Part of the USSR: Hymenoptera 3(2). Amerind Press Pvt. Ltd., New Delhi.]

Manuscript received: 21 February 2014

Manuscript accepted: 1 July 2014

Published on: 15 October 2014

Topic editor: Koen Martens

Desk editor: Kristiaan Hoedemakers

Printed versions of all papers are also deposited in the libraries of the institutes that are members of the EJT consortium: Muséum National d'Histoire Naturelle, Paris, France; Botanic Garden Meise, Belgium; Royal Museum for Central Africa, Tervuren, Belgium; Natural History Museum, London, United Kingdom; Royal Belgian Institute of Natural Sciences, Brussels, Belgium; Natural History Museum of Denmark, Copenhagen, Denmark. 